\title{
sciendo
}

\section{The reform of 2007 on regulation of the market of legal services in England and Wales as an institutional experiment}

\author{
Michał Masior ${ }^{1}{ }^{a}$ Zbigniew Staniek ${ }^{b}$ \\ ${ }^{a}$ SGH Warsaw School of Economics, ul.Niepodleglosci 162, 02-554, Warsaw, Poland \\ ${ }^{\circ}$ PWSC Kalisz, ul. Nowy Swiat 4, 62-800 Kalisz, Poland
}

(C) 2019 Michat Masior, Zbigniew Staniek. This is an open access article distributed under the Creative Commons Attribution-NonCommercial-NoDerivs license (http://creativecommons.org/licenses/by-nc-nd/3.0/

DOI 10.2478/WSBJBF-2019-0012

\begin{abstract}
The article presents a reform that provides a regulatory framework for the legal services market, implemented as the Legal Services Act of 2007 in England and Wales. The reform was intended to systematise the institutional system of that market, to increase its transparency, to increase the role of competition and to enhance the position taken by customers at the expense of the current legal self-regulatory bodies. The reform involved development of a multi-level management structure for institutions-organisations that supervise or represent lawyers handling various market segments. A new form of functioning was provided to lawyers in order to facilitate acquisition of capital and know-how. A new package of supervisory measures was initiated and applied to operations undertaken by lawyers and their companies. The aim of this case study is an attempt at evaluating the above-mentioned reform and drawing conclusions for model operation of the legal services market. In order to achieve such an aim, the institutional change is described based on the current data about the functioning of regulators, taken from their websites. The article also refers to literature related to regulation of legal professions and the English-Welsh context. The conclusions that have been drawn prove the advisability of its implementation. For the sake of economic and social evaluation of the outcomes of the applied solutions, the dynamics of the rates describing market operation (supply, prices, demand, consumer choice) has been analysed. It has been stated that since the implementation of the reform in 2008, the accessibility of legal assistance has been increased along with the quality of legal services and market competitiveness. However, the authors of the reform have been disappointed with the scarce interest in new forms of development provided to legal companies, innovation for licensed lawyers and further increase in prices of legal services. A demand barrier has been also encountered. Despite all those facts, the value of the legal services market in England and Wales has been increased and export of legal services and the number of licensed lawyers have also grown. Furthermore, the reform has already found its followers in other countries.
\end{abstract}

Key words: lawyers, institutions, regulations, legal services

\section{Introduction}

Economic institutions determine economic growth and distribution of resources. They encourage or discourage interested parties from particular actions, and they affect economic performance (Robinson, Acemoglu \& Johnson, 2004). A fundamental institution of market economy and, at the same time, an economic institution, as understood by the above-mentioned authors, is the market. The functioning of the market institution also depends on some

\footnotetext{
1 m.masior@gmail.com
} 
other institutions, according to the classification provided by J. Wilkin and M. Iwanek, that is, standards (including law) and organisations (relations of individuals and groups of common interests and features characteristic for dominating behaviour) (Wilkin \& Iwanek, 1998). A specific example of the market that illustrates the complexity of the impact exerted by three above-mentioned types of institutions is the market of legal services.

It is worth analysing the market of legal services because of its contribution to welfare, jobs, growing turnover in developed economies, advancing juridicisation of social life (with high participation of the EU legislation), a decreasing role of informal institutions (trust or moral standards) and growing complexity of economic and social relations in the era of globalisation. The way of its operation determines the level of transaction costs in trading, because lawyers make law application easier, especially considering the fact that it is very complicated. Law comes as the most important formal institution in political systems based on the rule of law.

A characteristic feature of the legal services market is its high regulation level, which is manifested by the entry barriers to the sector and restrictive principles related to the practising of legal professions and provision of legal services. Commonly in the world, legal self-regulatory bodies are usually responsible for the approval and execution of the principles that refer to the entering and the practising of legal professions. Next to critical sociology, economy sees that as a pursuit of benefits in which lawyers who have already been entitled to provide legal services take part, in order to limit the access to the market for other competitors and in order to discourage each other from price competition and excessive production that may lower the current prices.

In their studies, numerous authors (Abel \& Lewis, 1988; Semple, 2015; Stephen, 2013) discuss the significance of the role performed by lawyers who tend to protect the interests of their occupational groups. Legal services can be viewed as a field where the interests of customers, legal self-regulatory bodies, individual lawyers and public authorities, who are all interested in efficient judicature, clash. It happens in all countries, however, under various conditions of institutional solutions. At the same time, an important criterion of the market assessment is the extent to which the market allows the particular groups to pursue their partial interests and to pursue the public interests (Staniek, 2017).

The authors seek for an efficient model for regulation of the legal services market. Implemented in England and Wales, the reform of the regulation of that market provides some interesting empirical material, which is worth analysing, and the assessment of which comes as a direct aim of this article. An experiment that has taken place in England and Wales involves a change in the mechanisms applied in the allocation of resources on the supply side: from regulation of the market, through lawyers (self-regulation) to the model of regulation, in which the state has decisive - although indirect - influence (the so-called meta-regulation; cf. Coglianese \& Mendelson, 2010). Furthermore, some mechanisms are provided in order to increase the role of market coordination. The reform of the market has been intended to increase the implementation of the public interest that is identified with the interest of customers. The reform has also come as a result of a critical assessment of the way in which legal self-regulatory bodies operated and the whole system in which the market was regulated before 2007.

Hence, the following questions can be posed: How does the English-Welsh model of market regulation look like today? What institutions-organisations and formal institutions is it combined of? What functions do they perform (cf. Staniek, 2017)? Then, it should be decided whether theoretical assumptions withstand their confrontation with practice, and what are effects of the new management structure affecting the market for its competitiveness, the quality of services and their availability.

An institutional system on the particular market should be able to expertly minimise the unreliableness of the state and the market; the unreliableness of the state will differ, depending on the role which the state performs in the market of legal services - a role of the legal self-regulatory body, or, as in the example of England and Wales, a meta-regulator that supervises operation of legal organisations. Hence, the authors believe that it is worth assessing which form of regulation of the legal services market (meta-regulation or self-regulation) is better for the limitation of the above-mentioned unreliableness. Unreliableness of the legal services market should be particularly understood as asymmetry of information and external (positive and negative) effects. They indicate the need for state regulation through, for example, self-regulatory bodies or regulation agencies (institutionsorganisations), but such regulation also shows some imperfections. Unreliableness of the state in the market of legal services refers to the following: susceptibility of the regulators to the influence exerted by the interests of legal occupational groups, limited information, delays, costs related to bureaucracy and possible over-regulation. Moreover, whilst analysing the institutional environment of legal services, it is necessary to consider dependencies 
between formal and informal institutions in the process of providing legal services (the role of professional ethics and a model system of organisations that guarantee its execution).

The aim of the analysis presented in the article is to identify the characteristic features of the reform implemented in England and Wales and to assess its advisability, viewed from the perspective of social and economic objectives, to which the market of legal services serves. Such an aim will be achieved if some observations on the effects of regulation solutions applied in England and Wales (which have been copied in other countries) and on the advantages and disadvantages of the current and new forms of regulations are contributed to institutional economy (and also to sociology and law). Undoubtedly, it can be seen as a valuable reference point for other countries and regulation of other professional services. Considering the innovative and well-justified experimental character of the reform, it can be helpful in other changes brought to the regulation of markets, which increase the role of the market mechanism of resource allocation in a controllable manner. It seems that the article can provide some important contribution to the discussion on intelligent regulation of the market and controlled liberalisation in the era of the neoliberalism retreat.

The authors wish to refute a thesis about positive impact of the change in the regulation of the legal services market implemented in England and Wales in 2007 and its efficiency. The auxiliary hypotheses are the statements referring to the particular outcomes of the reform, such as its positive impact exerted respectively on the following: the size of the market, access to legal assistance, competitiveness of the market, innovativeness of service providers, a decrease in prices of services and an increase in the quality of legal services. According to the theory that refers to the pursuit of benefits, it can be expected that the limited role of lawyers in market coordination (decreased by the separation from the supervision which is discussed below) should bring positive outcomes for lawyers' customers. Following mainstream economics, it is possible to believe that after legal services have been subject to stronger competition and after the entry barriers to development of legal enterprises have been eliminated, there will be a wider choice provided for customers (measured by the number of lawyers, easy access to their services, etc.), lower prices and higher quality of services (measured by customers' satisfaction, innovation of the offer).

The subject of the analysis refers to the specific legislative solutions and the outcomes of their implementation, including economic outcomes in particular. The research method is case study that is adequate, considering the level of the complexity of the reform and the legal services market itself. An extensive discussion of the abovementioned subject in the article should allow readers to understand dependencies among the specific regulative solutions and the outcomes of their applications, viewed from the perspective of 10 years that have passed since the implementation of the reform. It should be also emphasised that the causal relation between the reform and its outcomes is not indicated with the use of control over the changes in the environment because - as in the case of any other real institutional change on such a large scale - it is impossible (in the same way as it is impossible to carry out a real experiment). The conclusions are based rather on a description of institutions, comparisons of the above-mentioned values, made between the time periods - before and after the reform - and the results obtained after the analysis of regulators in that market. A relatively stable economic environment, the size of the population and the lack of any other institutional changes of that type on the market during the analysed period increase the reliability of the comparisons made between the time periods.

The analysis is mainly based on the data obtained from the websites of organisations that represent or supervise lawyers in England and Wales, on the scientific analysis that has been commissioned by such organisations in order to assess the reform in some specific fields of its impact and on several publications referring to the regulation of the legal services market, which refer to the discussed reform and regulation of legal professions in England and Wales.

The structure of the article is as follows: the first part presents the characteristics of the legal services market, which is intended to justify its regulation. The second part indicates the reasons for the reform in England and Wales. The third part presents the main assumptions of the reform. Subsequently, in the fourth, the fifth and the sixth parts, the outcomes of the reform are characterised with regard to the accessibility of legal assistance, the quality and the competitiveness of the whole market of legal services. In conclusions, the results of the analysis are discussed and the main thesis is verified with some stipulations.

\section{The character of legal services}


The market of legal services has the structure of monopolistic competition. It is characterised by a large number of entities, similar but heterogeneous services and a significant role of non-price factors of competition (especially word-of-mouth marketing with consideration of legally limited possibilities for advertisement). The imperfect character of the market has some consequences for the allocation of resources, the structure of impulses and it affects social processes of management. The market is characterised by the occurrence of negative and positive external effects and various cases of information asymmetry. Legal counselling belongs to the category of trustrelated goods (Darby \& Karni, 1973), especially in relations between lawyers and their individual customers.

Lawyers can achieve some negative external effects by, for example, unduly delaying court proceedings, whereas positive effects should be achieved by professional participation in proceedings at court or at offices that allows interested parties to settle their cases and to enforce legal regulations. The significance of external effects in the form of impact exerted on judicature is greater in England and in Wales, where the system of the common law is in force (and the legislation content is based mostly on precedent, the formation of which is directly affected by lawyers) than in the countries based on the statutory law, such as Poland. Moreover, the significance of the rule of law should never be underestimated, as well as public good that is also created with the participation of lawyers and refers to the implementation of rights and obligations of citizens and institutional entities. In this way, they contribute to the implementation of legally protected values that improve cohesiveness of the society.

The rule of law performs a particular role in contemporary liberal democracies that are based on that principle. The concept of the state of law (Rechtastaat in German) was initially developed by Immanuel Kant. It assumes that the authority is subject to law and law protects civil liberties stated in the constitution. A guarantee to the protection of the civil rights is provided by courts, irrespective of the legislature and the executive power. It is also necessary, at the same time, to implement the rule of law, which means operation of the bodies of public authority exclusively based on the legal regulations and within its framework, with other entities respecting such legal regulations. It is also conditioned by the balance amongst the legislature, the executive power and the judiciary. Apart from the separation of powers, the concept of the state of law includes some other criteria related to the relations between the state and its citizens, for example, proportionality of public intervention or the nonretroactivity of law, which has been accepted in developed countries as a principle of their political systems (cf. Art. 2, Constitution of the Republic of Poland).

Considering such a context, it is possible to see the significant political, social and economic roles performed by legal counselling that comes as an element of the legal protection system. Legal counselling is most often a subject of commercial service provided on the market of legal services. Hence, the market itself is affected by other institutions, and as an institution of a certain type or kind, it provides execution of law (the legislature is essentially responsible for law enactment). The rights granted to citizens of particular countries and to institutional entities, which are within its jurisdiction (all of them are legal entities) and which will protect them along with the obligations they will have to respect, depend on the content of legal advice, opinions, agreements, methods of court representation, offices, education and ethics of lawyers and the impact exerted by their occupational groups.

Eventually, both in England and Poland, it is decided by judges (who articulate legal acts) who operate outside the market of legal services - not by representatives of independent legal professions who operate in the market. However, majority of legal problems are settled at the pre-litigation stage. Fortunately, litigation is usually of potential nature and the role of barristers, solicitors, tax advisors and so on comes down to legal analysis, the choice of methods adequate to protect customers' interests, avoidance of disputes and the skilful conducting of disputes if they should occur in the particular context of legal regulations, judicature and jurisprudence.

Legal services are services provided by lawyers on the market - not by those whose the only customer is judicature, including judges or prosecutors (work of bailiffs and notaries is of mixed nature). In Poland, such services are referred to as legal assistance, the full range of which is provided by barristers and solicitors. A narrower range of services is provided by patent attorneys, tax advisors and lawyers without occupational titles. Considering the vastness of the matter that undergoes legal regulation along with the complexity of social and economic relations, lawyers usually specialise in the particular fields. They also provide services to customers of different profiles: individual or institutional. Lawyers are employed at various law firms and also as corporate lawyers or office employees. Defined in such a way, the occupational groups and services they provide can be found in all countries, although the size of the sector, the types of cases commissioned to lawyers and the specificity of methods applied to settle such cases differ in terms of the level of development, culture and historical experience referring to the legal system. 
Legal services are not provided in an arbitrary or random way. People who are entitled to provide such services must have specific qualifications, and the way in which legal services are provided undergoes detailed regulation, considering their subjects, including goods particularly important because of material or personal reasons (freedom, dignity, health, family relations, etc.). Legal service providers must avoid conflicts of interests; they must respect the obligation of professional secrecy. They are subject to disciplinary responsibility, they must take additional professional courses, they must belong to occupational organisations, they cannot advertise their services and sometimes they cannot apply freely set prices and selected methods of payment for their services. Such rules are usually established by the occupational groups, and they are ethically justified. The supreme value that justifies the above-mentioned rules is lawyers' professionalism, which is also indirectly understood as the good of customers and judicature. Lawyers participate in judicature, providing legal assistance at various stages of court proceedings. Such regulation of the supply is intended to provide efficiency of the market - efficiency as understood by W. Pareto as well as adaptive efficiency. This type requires relatively easy access to legal assistance of high quality and readiness to pay a proper price for it.

\section{Situation before the reform of the legal services market in England and Wales}

In England and Wales, the question of the proper functioning of the legal services market became a subject of a political dispute. Lawyers were accused of limiting competition among service providers and of limiting the number of services provided, under the pretence that they cared for their customers (Abel, 1988). The system of regulation of legal services was considered to be anachronistic, inflexible, too complicated, non-transparent, nonobjective-based, non-principle-based and incoherent. It was considered that the system did not serve customers of legal services in an efficient way and it could not be controlled (Clementi, 2004; UK Department for Constitutional Affairs, 2004). The system of handling complaints by lawyers was determined as malfunctioning, regulation of the scope of legal services and their types was considered as selective, the network of legal organisations that used to regulate particular legal professions was said to be incoherent, inconsistent with customers' interests and hindering competition as well as regulation of acceptable organisational and legal forms.

Lawyers' anti-competitive practices had been the subject of interest since 1960s, when M. Zander published his book Lawyers and the Public Interest (1968) and the British Monopolies Commission presented a report on that subject (1967). Then, in 1979, the Royal Commission on Legal Services provided an analysis of the advisability of barristers' monopoly on court representation, solicitors' monopoly on conveyance services and division into two above-mentioned occupational groups. The review ended with the maintained status quo, although it was not done unanimously. In 1985, it was decided to end the monopoly of legal advisors on transferring legal titles to real estate from legal conveyance and to provide access to the market to a new occupational group of licensed conveyancers. In 1989, the government under the leadership of M. Thatcher issued a very liberal proposition related to changes in the occupation, but it faced a lot of violent criticism from lawyers, and eventually, almost nothing was changed. In 2001, the Office of Fair Trading published its report on competition in professions (Competition in Professions, Office of Fair Trading, 2001), in which a number of practices applied by representatives of various professions in order to limit the competition were identified. Also, some solutions similar to those presented in 1989 were suggested. As a result, the government under the leadership of T. Blair decided to provide an audit of the current system of legal service regulation. The audit was commissioned to Sir David Clementi, the President of Prudential, an assurance company. After the publication of the report in 2004, the government approved the assumptions for a draft act in 2005, and in 2006, the draft act was eventually adopted by the Parliament as the Legal Services Act (herein referred to as the LSA - the Legal Services Act). The Act received the royal assent in October 2007, and it came in force on 7 March 2008. Its implementation, including establishment of new institutions, took four years (Zander, 2011; Legal Services Board, 2018b).

\section{The Legal Services Act of 2007 (LSA)}

The LSA explicitly states the values that should be implemented by service providers, and therefore, the current institutional system has been changed. Next to occupational organisations and self-regulatory bodies, some independent regulative agencies have been established, which are responsible for their supervision, and amongst which, one agency is responsible for the implementation of supreme objectives related to regulation of legal services market. In that way, the competences of self-regulatory bodies have been limited, because they have lost 
the right to grant certifications required to perform particular professions, along with their disciplinary competences. Administrative supervision over the settlement of customers' complaints has also been implemented. Regulation of institutional entities providing reserved legal services has been commenced, and a possibility of providing such services has been opened for the so-called alternative business entities whose owners or managers are non-lawyers.

The aim of the LSA is to introduce more competition to the legal services market. Established based on the LSA, the institutional system is aimed at erasing historical differences amongst legal professions, motivating lawyers to perform a full range of better services to their individual and corporate customers and providing some basis for the development of legal firms (Boon, 2014). The LSA defines these objectives as follows: protection and implementation of public interests and the constitutional principle of the rule of law, an increase in accessibility to justice, protection and implementation of consumers' interests, an increase in competition among licensed service providers, an increase in citizens' awareness about their rights and obligations and the extent to which the principles of occupational ethics are respected. Hence, the assumptions of the reforms can be defined in the following way (Hook Tangaza, 2017):

- independence of regulation - the principles related to the admission and practice of legal professions should not be defined by self-regulation bodies that represent lawyers; in order to implement public aims, some organisations should be established, which will be independent from lawyers and from political factors related to the state and with the participation of non-lawyers;

- focus on aims and outcomes of regulation of legal services - the aims of regulation are defined in the LSA, obligations imposed on service providers can be different, but they should be helpful for the achievement of the aims. The particular regulators decide about imposing such obligations and they are held responsible for that; self-regulatory bodies used to indicate a tendency to increase the professional standards that also increased the regulative pressure on service providers. However, values such as access to judicature, competition and customers' interests used to be neglected;

- regulation of institutional entities and regulation based on risk - regulation refers to internal affairs of all companies that provide legal services, not only of companies with the participation of non-lawyers; such an attitude allows the interested parties to identify sources of possible problems and market tendencies and their anticipation before they start affecting customers; it offers a possibility of providing proper incentives for innovation;

- non-lawyers' ownership of companies - it allows the interested parties to obtain additional capital, technology and know-how from investors and experienced practitioners who wish to enter the sector for adequate remuneration; at present, one of the main reasons for solutions of that kind can be intention to develop technological innovation.

The supervision over the proper functioning of the legal services market is the responsibility of the newly established Legal Services Board (LSB). It is an agency that is independent from legal self-regulatory bodies and from the government. It is maintained from the contribution fees paid by lawyers. The Board grants accreditation to other organisations to perform supervisory functions over the particular legal occupational groups. In England and Wales, there are eight independent legal professions: solicitors, barristers (who deal mainly with court representation), legal executives or CILEx member lawyers, licensed conveyancers (who deal with the transfer of property rights), patent attorneys, trade mark attorneys, cost lawyers and notaries. Moreover, the LSB supervises regulation of chartered accountants. Lawyers from the particular occupational groups are members of their own legal associations, such as Bar Council, Law Society and Council for Licensed Conveyancers (see: Table 1).

The key mechanism implemented by the LSA is the separation of the representative functions from regulative legal organisations. The separation has been implemented in a very smart way - the responsibility for its implementation is entrusted to a legal organisation that has been granted accreditation to perform as an approved regulator for a particular legal profession. In practice, the current self-regulatory bodies have been granted such accreditation, and they continue to perform their functions, however, in a limited form. Their role has had to be limited to the function of representative bodies for lawyers who are their members. Disciplinary competences and the right to grant admission and right to practice particular professions must be delegated to other separate organisations that are defined by the LSA as independent regulators. These are, amongst others, Solicitors Regulation Authority (SRA) or Bar Standards Board (BSB). 
Both organisations, an accredited regulator and an independent regulator, may share administrative costs. Such relation is intended to provide closer cooperation, better information flow and enforcement of regulative decisions. Supervision over the performance of their functions is provided by the LSB. If the LSB is not satisfied with performance of an independent regulator, it may impose a sanction on the organisation representing lawyers' interests and withdraw the accreditation. Hence, for this organisation, it is not advantageous to enter an agreement with an independent regulator so that it should serve the interests of a particular occupational group (with an exception of a situation when the LSB remains unaware of such an agreement). Independent regulators grant the right to provide reserved legal services in the form of an authorisation for natural persons or a license for institutional entities.

Not only has the LSA changed the institutional system on the side of legal service providers so that the granting of professional qualifications should be based on objective criteria and any possible malpractice should be eliminated, but it has also increased the competition on the particular markets of legal services. None of the legal professions has retained its monopoly for services that it has so far provided, such as court representation and notary services related to real estate. At present, there are six types of reserved legal activities that are regulated by the LSA, and three types of services regulated on some other basis:

- court representation, which is the right to appear at court, to submit statements at court, including motions for evidence and examination of witnesses (LSA);

- handling proceedings, including instituting, conducting and performing activities that are related to the proceedings (LSA);

- performing reserved activities, including preparation of applications or other documents required in the process of conveyancing, in accordance with the Land Registration Act of 2002, including submissions (LSA);

- $\quad$ conducting succession proceedings related to inheritance under the will and under the intestacy statute (LSA);

- conducting notary activities involving the activities that were conducted by notaries when the LSA came into force, based on the Public Notaries Act 1981 (LSA);

- $\quad$ authenticating documents and taking administration of oaths, which means that they can authenticate official documents other than those prepared by themselves or by the opposite parties (LSA);

- $\quad$ providing services related to immigration (Immigration and Asylum Act, 1999 et al.);

- $\quad$ providing services related to claims management (Compensation Act, 2006);

- $\quad$ providing services related to insolvency (Insolvency Act 1986 et al.).

Table 1. Regulation of the legal services market in England and Wales

\begin{tabular}{|c|c|c|c|c|c|c|c|c|c|c|c|c|c|}
\hline $\begin{array}{l}\text { Segments of } \\
\text { the legal } \\
\text { services } \\
\text { market }\end{array}$ & $\begin{array}{l}\text { Accredited } \\
\text { regulators }\end{array}$ & $\begin{array}{l}\text { Independent } \\
\text { regulators }\end{array}$ & $\begin{array}{l}\text { Particular } \\
\text { occupational } \\
\text { groups }\end{array}$ & $\begin{array}{l}1,2 \\
\text { ABS }\end{array}$ & $\mathrm{a}$ & $\mathrm{b}$ & $\mathrm{c}$ & $\mathrm{d}$ & $\mathrm{e}$ & $f$ & G & $\mathrm{H}$ & I \\
\hline All & $\begin{array}{l}\text { The Law } \\
\text { Society }\end{array}$ & $\begin{array}{l}\text { Solicitors } \\
\text { Regulation } \\
\text { Authority }\end{array}$ & Solicitors & $\begin{array}{l}1,2, \\
\mathrm{ABS}\end{array}$ & $\mathrm{x}$ & $\mathrm{x}$ & $\mathrm{x}$ & $\mathrm{x}$ & & $\mathrm{x}$ & $\mathrm{x}$ & $\mathrm{x}$ & $\mathrm{x}$ \\
\hline All & Bar Council & $\begin{array}{l}\text { Bar Standards } \\
\text { Board }\end{array}$ & Barristers & $\begin{array}{l}1,2, \\
\text { ABS }\end{array}$ & $\mathrm{x}$ & $\mathrm{x}$ & $\mathrm{x}$ & $\mathrm{x}$ & & $\mathrm{x}$ & $\mathrm{x}$ & $\mathrm{x}$ & \\
\hline All & $\begin{array}{l}\text { Chartered } \\
\text { Institute of } \\
\text { Legal } \\
\text { Executives }\end{array}$ & $\begin{array}{l}\text { CILEx } \\
\text { Regulation }\end{array}$ & $\begin{array}{l}\text { CILEx } \\
\text { members } \\
\text { Chartered } \\
\text { legal } \\
\text { executives }\end{array}$ & 1,2 & $\mathrm{x}$ & $\mathrm{x}$ & $\mathrm{x}$ & $\mathrm{x}$ & & $\mathrm{x}$ & $\mathrm{x}$ & & \\
\hline $\begin{array}{l}\text { Intellectual } \\
\text { property }\end{array}$ & $\begin{array}{l}\text { Chartered } \\
\text { Institute of } \\
\text { Trademark } \\
\text { Attorney }\end{array}$ & $\begin{array}{l}\text { Intellectual } \\
\text { Property } \\
\text { Regulation } \\
\text { Board }\end{array}$ & $\begin{array}{l}\text { Trade mark } \\
\text { attorneys }\end{array}$ & $\begin{array}{l}1,2 \\
\text { ABS }\end{array}$ & $\mathrm{x}$ & $\mathrm{x}$ & $\mathrm{x}$ & & & $\mathrm{x}$ & & & \\
\hline
\end{tabular}




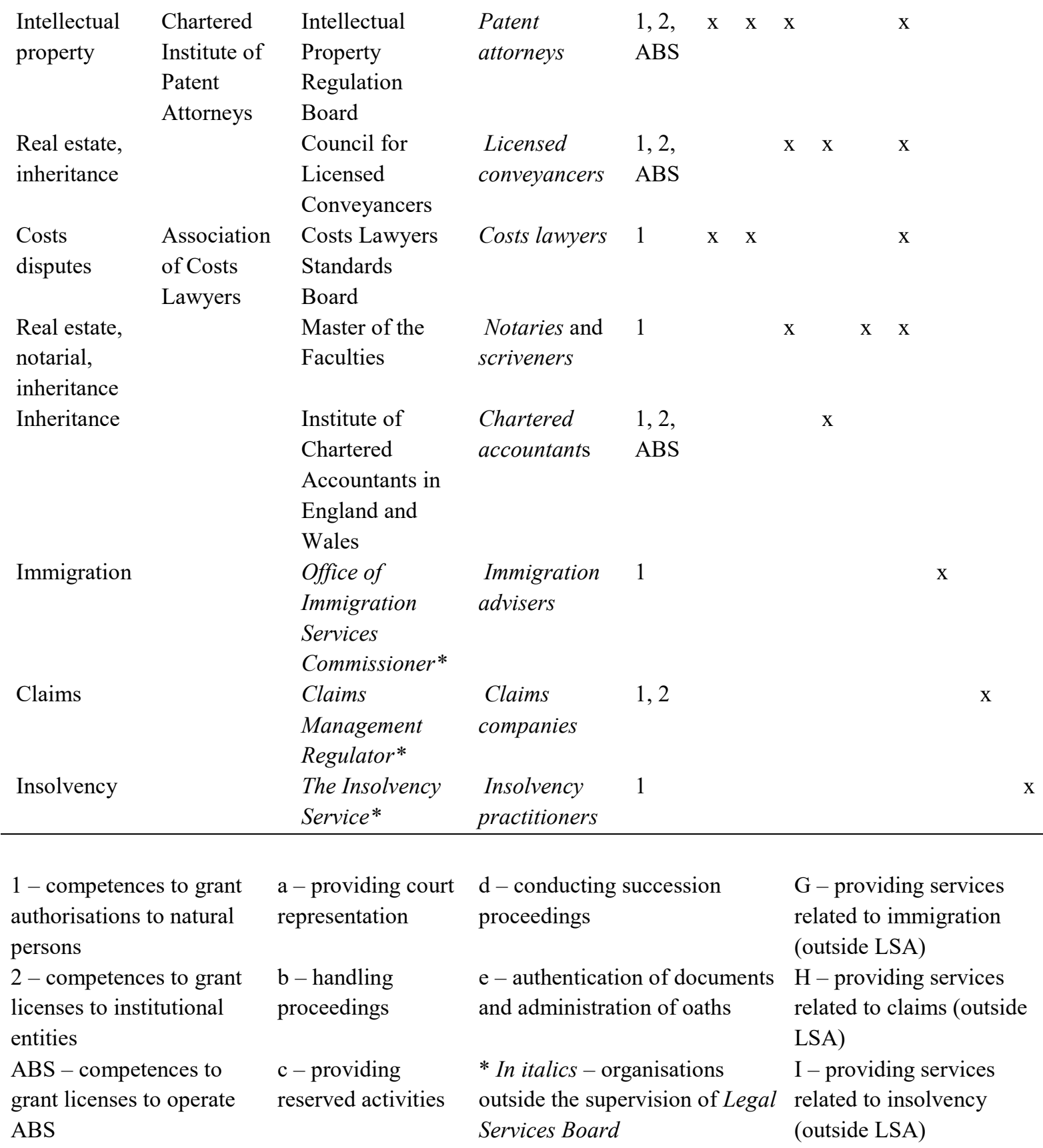

As it has been already mentioned, some independent regulators have competences to grant licenses for providing selected reserved legal services to institutional entities (entity regulation) and some can do that to so called alternative business structures (ABS licensing). ABS are entities that are not managed exclusively by lawyers or do not entirely belong to them. Traditionally, legal companies had to be owned and managed only by people with legal qualifications. Institutional entities (licensable bodies) that apply for licenses must meet numerous formal requirements defined in the LSA, which refer to their internal organisation, business premises and fees (cf. Annex 11 to the LSA). ABS must meet the same requirements. The first entity registered as an ABS was Co-operative Legal Services, which received its license from Solicitors Regulation Authority in 2012. The concept behind admission ABS to the market was to allow legal firms to expand through the access to capital and know-how provided by new investors and professional managers in order to take the advantage of the economy of scales and scope, to lower prices, to increase quality for customers and to provide better access to court, flexibility and wider choice of jobs for lawyers.

Whilst providing the characteristics of the new institutional system implemented by the LSA, it is impossible not to mention the Legal Services Consumer Panel, the Solicitors Disciplinary Tribunal and the Office of Legal 
Complaints. Legal Services Consumer Panel represents interests of both individual and institutional customers, and it supports the LSB in market supervision. The participation of customers in the supervising body and regular market research come as the best proof that the attitude towards regulation has been changed in order to serve customers, not lawyers. The Solicitors Disciplinary Tribunal adjudicates upon disciplinary cases of 145,000 solicitors who practice their profession and upon 11thousand companies they run.

The Office of Legal Complaints provides services to Legal Ombudsman. It handles citizens' complaints referring to regulated entities that provide reserved legal services, lawyers and institutional entities. It also handles complaints referring to services related to claims. The subjects of complaints are usually poor services. Before the LSA came into force, each professional organisation had dealt with complaints that referred only to their own members. At present, the office can force service providers to return or to decrease the costs incurred by customers, to pay compensation, to provide additional services in order to settle the cases, to apologise to customers or to return documentation. However, customers must follow the complete path of complaint procedures, starting with a complaint made to a service provider first (Legal Ombudsman, 2018).

\section{Availability of legal assistance}

In order to provide an assessment of the experiment, it is necessary to refer to three criteria, namely, availability of legal assistance, its quality and market competition (Legal Services Board, 2016). Availability to legal assistance and its proper quality guarantee justice for the society. Subsequently, growing competition strengthens market efficiency (ability to eliminate surplus and deficit).

The supply of services in the market has been increased, considering a higher number of licensed lawyers (by $22 \%$ between the years 2010 and 2018, from 142,000 to 177,000). About $83.8 \%$ of them are solicitors and $8.8 \%$ are barristers. The number of lawyers in England and Wales is one of the highest in Europe: 259 barristers and solicitors only for 100,000 citizens in 2016, with an average of 168 (CEPEJ, 2018). According to the data of 2018, it was already as many as 301 . At present, apart from licensed lawyers, there are approximately 130,000 nonlicensed lawyers who provide legal assistance. The number of institutional non-ABS entities with licenses to provide reserved legal services is stable, and it fluctuates at the level of 10,100-10,400. So far, 1,100 entities have already used the opportunity to establish ABS. This result is lower than that expected by the regulator, but it is improved every year. On an average, 200 entities receive their licenses to operate ABS every year. At present, there are five regulators who are competent to grant licenses for operating ABS (Legal Services Board, 2018a).

Regardless of the changes that have taken place on the side of the supply, the demand for legal services - at least, in the segment of services provided to individual clients - seems to be decreased. More and more people try to handle their legal problems by themselves, and fewer of them seek for the assistance of specialists. The reason for that situation might be availability of technologies (e.g. ready-made fill-in forms for customers) and legal facilitation of handling cases at court without any representation (Legal Services Board, 2016). The percentage of cases with court representation has been decreased in each type of cases. As a rule, the most difficulties in availability of legal assistance are experienced by the poorest and the weakest. Solutions that are intended to meet their needs, such as free legal assistance, are inefficient because of low legal awareness. The factors that additionally impede such solutions are law complexity, limited access to free legal assistance and the lack of understanding the role of legal service providers. Those who contact lawyers often receive poor-quality service, inadequate advice or perceive services as too expensive in relation to what they have received. The complaint procedures are also problematic for customers. Moreover, customers' expectations towards lawyers change.

According to some surveys, only $83 \%$ of English and Welsh people who have experienced some legal problems for the past 3 years decide to undertake some steps to solve them, only $43 \%$ of them go to get some advice from a specialist (others try to solve their problems independently or with their families and friends) and only $20 \%$ of them go to licensed lawyers (bdrc intercontinental, 2012; Legal Services Board, 2018a) - 18\% of them go to consult their problems with solicitors, $0.9 \%$ of them go to consult with licensed conveyancers and $0.5 \%$ of them go to consult with barristers (lower percentage results correspond to other occupational groups of lawyers). Other solutions involve visits at legal advice bureaus (5\%), offices and the Police (maximum 1-2\%), etc.

First, it means that an improvement in the quality of legal services provided by licensed lawyers has not been necessarily translated into an improvement of standards in the whole market, and the reform implemented by the LSA, however, very ambitious, has not included all the entities providing legal assistance. Second, it will take 
some time to observe the outcomes of the reform in the market since the implementation of the reform and commencement of activities undertaken on a larger scale by new regulators. Third, any possible change in the quality does not have to result from regulative changes. The problem of legal awareness does not refer to institutional entities as a rule, except for some small firms.

Considering such a context, the reason for which the LSB emphasises the significance of activities undertaken to raise citizens' legal awareness and to encourage them to use services offered by professionals is not surprising. Potential customers' inadequate assessment of costs and benefits obtained from using services provided by lawyers come as some of the reasons for insufficient demand. The survey commissioned by the Legal Services Consumer Panel in England indicates that the main barriers to the access to professional legal assistance are prices of such services and the lack of information concerning the offers presented by various service providers. For customers, the most important factor that affects their choice of lawyers is the price of their services (weight $75 \%$, data of 2015), and the cost of such services is usually perceived as high. Small companies still believe that legal assistance does not pay off for them.

The Solicitors Regulation Authority sees an important role of legal firms in solving such problems by their further development, innovation, the use of non-standard business models (ABS) and artificial intelligence, breaking the offer of legal services into specific services offered at (possibly fixed) lower costs that are more understandable for customers, differentiation of prices and lowering them for the customers in need, simplification of the language applied in the legal sector, online communication and communication via electronic communicators in order to fasten the exchange of information (Solicitors Regulation Authority, 2017).

\section{Quality of legal services}

Implemented by the LSA, the institutional environment should be more supportive for the efficiency of the market because the principles of competition and their execution mechanisms have been changed. Considering the changes in the institutional environment, the following should be mentioned:

- separation of the supervision over the functioning of the market from entities that undergo supervision (because of the appointment of independent regulators) and holding independent and accredited regulators accountable for their performance by the meta-regulator, LSB; regulators define and institutionalise standards for the professionalism of licensed lawyers and institutional entities;

- increased mechanisms promoting good practice and occupational deontology - such activities are implemented jointly by independent regulators and accredited regulators (organisations representing lawyers) and these include events organised in the legal sector, facilitation of contacting stakeholders or occupational integration;

- implementation of a mechanism for revoking the right for practicing legal professions (licenses, practising certificates); licenses (i.e. a register of people holding specific rights, for example, solicitors) must be renewed every year; hence, their revoking is an option. It motivates lawyers to prove their professionalism; each year, they must decide whether to renew their licenses or not; institutional entities do not have to renew their licenses;

- active regulation of the market by the LSB and independent regulators, which involves regular market research and identification of barriers in order to implement the objectives stated in the LSA and to undertake activities to overcome such barriers; such an active approach towards regulation of the market was not applied by self-regulatory bodies before;

- activities undertaken by accredited and independent regulators in order to improve the profession entry criteria (unification of standards and better verification of professional skills), for example, the SRA intends to implement one qualifying examination (Solicitors Qualifying Examination) and the BSB has been working on a change to the path towards professional accreditation for barristers (the Future Bar Training project), and it conducts an examination for the candidates who wish to become barristers after a professional training course (Bar Professional Training Course).

All the above-mentioned solutions favour higher professionalism of service providers, such as execution of its proper level to enter the market, imposing sanctions on any deviation from the standards of professional practice and dissemination of such standards. All that should be translated into proper quality of legal services. It can be immediately observed that general trust towards lawyers is maintained at an unchanged level, namely, 
approximately $45 \%$. More trusted professions are only physicians ( $80 \%$ approximately) and teachers $(70 \%$ approximately) (Legal Services Board, 2018a).

The data provided by the LSB indicate an increase in professionalism of lawyers in the years 2011-2017. It is proved by, first of all, a decrease in the number of well-justified complaints against solicitors (by $>70 \%$ ), the number of orders of the Solicitors Disciplinary Tribunal (by approximately $40 \%$ ) and interventions undertaken by the Solicitors Regulation Authority (by approximately 60\%) between the reporting years 2008/2009 and 2015/2016.

Hence, it is possible to state that the level of satisfaction from legal services has been increased. Despite the growing number of complaints against entities that are regulated by the SRA, the number of complaints that are settled by those entities themselves has been increased. New business models applied by such entities allow them to settle complaints efficiently. The number of complaints submitted to the Legal Ombudsman has been decreased over the past few years. The number of disciplinary cases has also been decreased, although some offences are quite serious. A measure of reliability of British service providers is export of their legal services, which was increased by 33\% in 2014 in comparison to 2007 (Legal Services Board, 2016).

It should be noticed that the prevalence of submitting complaints against lawyers has been decreasing, despite reinforcement of customers' interests by the performance of the Office for Legal Complaints. The percentage of customers who did not submit any complaints against service providers even though they were dissatisfied with their services increased from $42 \%$ in 2012 to $49 \%$ in 2017. Moreover, a general tendency towards submitting complaints about legal services decreased from $51 \%$ in 2011 to $44 \%$ in 2017.

\section{Competitiveness}

At present, the British sector of legal services plays an important role in economy, and it is manifested in numerous different macro-economic rates: it provides jobs to 370,000 people, it accounts for the added value at the amount of GBP 24.4 billion (2016), which is $1.4 \%$ of the British GDP; export of legal services generates GBP 3.4 billion surplus in the balance of trade in Great Britain. In the years 2005-2015, the sector was developed at the rate that was three times higher (3.3\% annually) than for the whole British economy (1.2\%). The British market comes as $27 \%$ of the European market of legal services (2015) and 7\% of the global market. The United Kingdom includes three jurisdictions: England and Wales, Scotland and Northern Ireland. The largest part of the market is in England and Wales (at least $63 \%$ of employment in the discussed sector). England and Wales comes as the jurisdiction that is often selected by companies. Each pound of additional revenue in the sector is to generate GBP 1.39 of revenues in other economic sectors.

The competitive pressure on the market of legal services has been increasing. It is proved by quite a stable number of legal firms in relation to the growing number of lawyers and also by the fact that many firms have decreased their costs and employment. Some of them have withdrawn from unprofitable segments of the market.

Innovativeness has been maintained at the level that is almost the same as it was after the reform had come into force, with exception of the ABS segment. The research survey indicates that the ABS have met expectations with regard to promotion of innovation and diversity on the market of legal services. Alternative business entities run by solicitors implement more new legal services than other entities (by 13-15\%). Moreover, solicitors are more innovative than any other providers of legal services. It means that they introduce more organisational and managerial changes in their organisations. Innovation is manifested, first of all, by extended offers, improved quality and the number of new customers who have been attracted (Roper, Love \& Bourke, 2015).

Between the years 2011 and 2017, individual customers indicated growing tendencies towards comparing offers presented by different lawyers (from 19\% to 27\%) and towards the common use of tools applied to compare offers presented by lawyers (which was still maintained at a very low level: $1-2 \%$ ). For that reason the easiness in selecting lawyers was decreased (from $51 \%$ to $47 \%$ despite the prior increase to $57 \%$ in 2016). Satisfaction of individual clients from the relation of the value of the services to their prices was slightly increased (from $57 \%$ to $61 \%)$.

Customers' low tendency towards comparing various offers presented by lawyers can result from a difficult access to information about prices (e.g. only every sixth lawyer who dealt with succession cases, family and property cases published their prices on their websites), scarce advertisement and the lack of professional websites that would be helpful in comparing prices. Prices of legal services grow as fast as prices of accounting services and much faster than prices of legal advisory services provided to business (Legal Services Board, 2018a). Their 
differentiation in various categories of services provided to individual customers is quite high, especially in divorce and succession cases with the participation of the inheritance administrator. The increase in prices can be explained with growing wages.

Customers do not see any difference between regulated and non-regulated (alternative) service providers they are often surprised that some services are non-regulated (hence, they do not undergo any supervision and are under no obligatory insurance). The lower level of regulation is usually followed by lower prices: alternative entities often charge less, for example, licensed conveyancers, in comparison to more restrictively regulated solicitors (Legal Services Board, 2017b).

\section{Conclusions}

The article briefly presents the institutional system in the English-Welsh market of legal services, and it also discusses its impact on market efficiency. The new system has been intended to increase transparency and friendliness of the market to customers and also to support management by objectives. It has also been intended to support development of legal firms in providing some more attractive offers to their customers (e.g. due to the new ABS format). The separation of representation from regulation has been planned as a tool to improve lawyers' professionalism. The rights to provide reserved legal services have been extended in order to increase competition. Regulations for almost the whole market have been unified. Institutions-organisations responsible for the implementation of the objectives have been established (the Legal Services Board, independent regulators, the Office of Legal Complaints) in order to respond to current needs.

In conclusion, it is worth emphasising some characteristic features of the reform that is par excellence of institutional nature. First, legislative changes have been prepared in a thoughtful way, preceded by some comprehensive and detailed research by $\mathrm{D}$. Clementi who has been appointed to that task by the British government. Poland could definitely follow such brave and carefully prepared solutions in response to current social needs. Second, the resistance of the current organisations that represent lawyers, such as the Law Society or the Bar Council, has been weakened by the preservation of some competences granted to them previously. In that way, the institutional continuity has been preserved. The reform has introduced the supervision of the LSB and Lord Chancellor over the performance of such organisations, which motivates them to do their best for the implementation of values declared in the Art. 1 of the LSA, because otherwise they risk a complete loss of their current competences. Before that, no one was entitled to verify the outcomes of their work in terms of the implementation of values such as public interest, rule of law, customers' interests and access to justice of protection of competition. Third, the whole managerial structure is based on the combination of stimuli, incentives and punishment: Lord Chancellor appoints members of the LSB, the LSB supervises work of regulators accredited under the LSA (such as the Law Society), accredited regulators must guarantee establishment of independent regulators (such as the Solicitors Regulation Authority) who directly supervise lawyers and firms that provide legal services within the limits of their competences.

Hence, the organisation of regulators is arranged in a way that should minimise organisational shortcomings of the state (such as imprecise principles, inefficiency, inflexibility, lack of control possibilities). Considerable transparency of their operation (even on their websites) increases trust towards their activities. Regulation based on many organisations, including some new ones, is quite expensive but the costs are covered by service providers themselves, and they decide whether they will provide specific services or not. It can be observed that the applied method of regulation has only indirectly changed the conditions of competition because there is no place for fiscal instruments (subsidies or taxes) or for price regulation. Market behaviour is coordinated in order to efficiently counteract any malpractice of service providers (who have informational advantage over their customers) and to promote good practice (e.g. due to the ABS, companies benefitted from the scale and scope). The allocation of goods on the market takes place in the commercial manner, and it guarantees a certain level of its efficiency (as understood by Pareto).

Whilst characterising the institutional system of the legal services market in England and Wales after the implementation of the LSA, it is necessary to emphasise that - apart from the discussed structure of institutionsorganisations - the system is also formed by other formal (first of all, ethical principles that are defined by accredited and independent regulators) and informal (customs) institutions. Both categories of these institutions have certainly been changed by the implementation of the LSA (liberalisation of the forms of professional practice, new reporting obligations); however, they are not the main subject of the article. 
The available data do not allow the authors to refute the thesis about the positive influence exerted by the reform of the legal services market in England and Wales. The supply of legal services has been increased (an increase in the number of licensed lawyers by $22 \%$ ) as well as the diversity of entities that provide such services (e.g. 1,100 alternative business entities have been established). At the same time, the demand has been remained at a similar level and prices have been mostly growing.

Surely, regulators face a challenge related to the fact that licensed lawyers who are under their control account for at most $20 \%$ of the demand for legal assistance. Most citizens of England and Wales do not really seek for specialist assistance. Those who do, after the implementation of the LSA, are less likely to submit complaints, but they are more willing to compare offers presented by various service providers. Regulators of the supply do not have any influence on the demand; they can only try to adjust service providers' practice in the best way to meet customers' expectations (e.g. encourage them to publish their price lists, to apply new technologies or to communicate the fact that they undergo regulation) and in that way to indirectly change customers' habits (such experience can be also valuable in other countries because low legal awareness seems to be quite a universal problem, also in Poland). A negative aspect of regulators' presence that can be observed is weaker innovativeness indicated by licensed lawyers in comparison to non-licensed ones.

Moreover, there are no negative outcomes of the reform that would affect the quality of services provided. A decrease in the number of well-justified complaints, orders and interventions regarding solicitors, who form the largest group of regulated lawyers, and a decrease in the number of disciplinary cases prove higher professionalism of lawyers and higher satisfaction of customers.

Higher efficiency of allocation is proved by higher competition pressure on the market. Similar to Poland, since 2005, an increase in the number of lawyers has resulted in lower operating costs of legal companies. Higher competition in the sector has probably contributed to an increase in foreign demand for services provided by English and Welsh lawyers, which is proved by a surplus in the balance of trade of Great Britain with regard to legal services (at present, Brexit can weaken the dynamics of export). As a result of an increase in the supply and prices, the value of the market has also been increased (three times faster than the whole British economy until 2016). It has been also translated into a higher added value in sectors that use professional services at the lower levels of the value chain.

Paradoxically, active intervention of the state has been necessary to liberalise the market and to improve its efficiency. As the positive outcomes of the LSA referring to the quality of legal services and to an increase in the number of lawyers may suggest, it has resulted from the excessive domination of lawyers' interests before the implementation of the LSA. The presented analysis comes as a case study that refers to a particular institutional change made to the conditions in which legal professions are practised. However, the results of that change can be interesting also in terms of other institutional changes and other professions, especially those that are granted the privilege of self-regulation (legal services are usually regulated in that way). As it can be observed in practice, the LSA has globally affected the regulation of legal professions, especially in the countries based on the common law system, such as Ireland, Canada, the United States, Australia, the RSA, Singapore, Denmark and the Netherlands, where the solutions applied in the LSA have been adopted. The political objectives of the European Commission, such as optimisation of the restrictive character of professional principles and intensification of the service sector, correspond to the objectives of the English-Welsh reform. Moreover, an innovative approach, which involves objective-based regulation applied in the EU legislature to a much higher extent than that in national legislatures, encourages a critical analysis of the regulation methods applied in the particular markets in Poland. The example of England and Wales indicates that efficient regulation of the market sometimes requires a complex managerial structure and precise instruments with consideration of various values and conditions.

\section{References}

Abel R. (1988). England and Wales: A Comparison of the Professional Projects of Barristers and Solicitors. [in] R. Abel \& P. Lewis (eds.), Lawyers in Society: Vol. 1. The Common Law World. Berkeley and Los Angeles: University of California Press.

bdrc intercontinental (2012). Legal Services Benchmarking. https://research.legalservicesboard.org.uk/wpcontent/media/2012-Individual-consumers-legal-needs-report.pdf. 
Boon A. (2014). The Ethics and Conduct of Lawyers in England and Wales. Oxford and Portland, Oregon: Hart Publishing.

CEPEJ (2018) or Commission européenne pour l'efficacité de la justice. European judicial systems - Edition 2018. https://public.tableau.com/profile/cepej\#!/vizhome/CEPEJ-Explorerv4_0/Tables.

Clementi D. (2004). Review of the regulatory framework for legal services in England and Wales. http://webarchive.nationalarchives.gov.uk/+/http:/www.legal-servicesreview.org.uk/content/consult/consult_reviewpaper.pdf.

Coglianese C. \& Mendelson E. (2010). Meta-regulation and Self-regulation. [in] R. Baldwin, M. Cave \& M. Lodge (eds.), The Oxford Handbook of Regulation. Oxford, UK: Oxford University Press.

Darby M. \& Karni E. (1973). Free Competition and the Optimal Amount of Fraud. Journal of Law and Economics, 16, 67-88.

Hook Tangaza (2017). The global impact of the Legal Services Act 2007. http://www.hooktangaza.com/node/124.

Legal Ombudsman (2018). Helping the public. http://www.legalombudsman.org.uk/helping-the-public.

Legal Services Act 2007, c. 29. http://www.legislation.gov.uk/ukpga/2007/29/introduction.

Legal Services Board (2016). Evaluation: Changes in the legal services market 2006/07 - 2014/15 - Summary. https://research.legalservicesboard.org.uk/wp-content/media/2015-2016-FINAL-Market-Evaluation-Mainreport1.pdf.

Legal Services Board (2017a). Annual Report and Accounts for the Year Ended 31 March 2017. http://www.legalservicesboard.org.uk/news_publications/publications/pdf/2017/LSB_Annual_Report_and_Acc ounts 201617 WEB.pdf.

Legal Services Board (2017b). Prices of Individual Consumer Legal Services. https://research.legalservicesboard.org.uk/wp-content/media/Prices-of-Individual-Consumer-Legal-Services2017-FINAL-MAIN-1.pdf.

Legal Services Board (2018a). The LSA: past, present, future. http://www.legalservicesboard.org.uk/news_publications/speeches_presentations/2018/Robert_Cross__UCL_masters_students_March_18.pdf.

Legal Services (2018b). Board History of the reforms. http://www.legalservicesboard.org.uk/about_us/history_reforms/index.htm.

Lewis P. (1988), Introduction. In R. Abel \& P. Lewis (eds.), Lawyers in Society: Vol. 1. The Common Law World. Berkeley and Los Angeles: University of California Press.

Office for Fair Trading (2004). Competition in Professions. http://webarchive.nationalarchives.gov.uk/20140402172414/http://oft.gov.uk/shared_oft/reports/professional_bo dies/oft328.pdf.

Robinson J., Acemoglu D. \& Johnson S. (2004). Institutions as the Fundamental Cause of Long-Run Growth. NBER working paper series no. w10481. Cambridge, Massachusetts: National Bureau of Economic Research.

Roper S., Love J., Rieger P. \& Bourke J. (2015). Innovation in legal services. https://research.legalservicesboard.org.uk/wp-content/media/Innovation-Report.pdf.

Semple, N. (2015). Legal Services Regulation at the Crossroads. Justitia's Legions, Cheltenham, Great Britain; Northampton, Massachusetts, USA: Edward Elgar Publishing.

Solicitors Regulation Authority (2017). Improving access - tackling unmet legal needs.pdf. https://www.sra.org.uk/risk/resources/legal-needs.page.

Staniek Z. (2017). Ekonomia instytucjonalna: dlaczego instytucje sa ważne. Warszawa: Difin.

Stephen F. (2013). Lawyers, markets and regulation. Cheltenham, UK: Edward Elgar Publishing.

UK Department for Constitutional Affairs (2004), Review of the Regulatory Framework for Legal Services in England and Wales. Consultation Paper, http://webarchive.nationalarchives.gov.uk/+/http:/www.legal-servicesreview.org.uk/content/consult/consult_reviewpaper.pdf.

Wilkin J. \& Iwanek M. (1998). Instytucje i instytucjonalizm w ekonomii. Warszawa, the Faculty of Economic Sciences at the University of Warsaw

Zander M. (2011). The Legal Services Act 2007: An Act of Revolution for the Legal Profession. https://c.ymcdn.com/sites/ncbp.org/resource/collection/F9556696-FF20-442A-B922-

0FE6CFD2FB3E/The_Legal_Services_Act_2007.pdf. 